\title{
LEARNING MATERIAL DEVELOPMENT OF ESSAY WRITING THROUGH PLAN AND WRITE IN STKIP MUHAMMADIYAH KOTABUMI
}

\author{
Rulik Setiani \& Dewi Sri Kuning *)
}

\begin{abstract}
ABSTRAK
Penelitian ini merupakan penelitian dan pengembangan (R\&D). Tujuan penelitian ini untuk mengembangkan bahan ajar menulis esai (Essay Writing) melalui PLAN dan WRITE di STKIP Muhammadiyah Kotabumi dan untuk mengetahui efektifitas bahan ajar menulis esai terhadap hasil belajar mata kuliah Essay Writing. Metode yang digunakan dalam penelitian ini menggunakan metode R\&D yang terdiri dari 10 langkah namun peneliti hanya membatasi sampai dengan langkah ketujuh antara lain: studi pendahuluan, pengumpulan data, desain/penyusunan bahan ajar, validasi bahan ajar, revisi bahan ajar, ujicoba bahan ajar, dan yang terakhir revisi produk bahan ajar. Bahan ajar yang disusun terdiri dari $7 \mathrm{Bab}$ /Unit, bahan ajar disusun merujuk pada buku panduan akademik dan Rencana Pembelajaran Semester (RPS) dalam satu semester yaitu untuk mahasiswa semester 3 Prodi pendidikan bahasa inggris. Bahan ajar juga telah divalidasi oleh dua ahli materi dan satu ahli desain dan media, berdasarkan hasil dari validasi bahan ajar oleh ketiga ahli tersebut bahwa bahan ajar termasuk dalam kategori sangat baik dan layak untuk diujicobakan. Ujicoba melalui tes menulis esai dan angket. Berdasarkan hasil tes dapat disimpulkan bahwa bahan ajar yang telah dikembangkan sangat efektif untuk pembelajaran mata kuliah Essay Writing, itu dibuktikan dengan nilai rata-rata kelas 3B yaitu 80,3 lebih tinggi dibandingkan nilai rata-rata kelas $3 \mathrm{~A}$ yaitu 74,4 , sedangkan berdasarkan hasil angket, ketiga aspek bahan ajar termasuk dalam kategori sangat baik.
\end{abstract}

\section{Kata-kata Kunci: Pengembangan Bahan Ajar, Essay Writing, dan Plan dan} Write.

\section{INTRODUCTION}

\subsection{Essay Writing}

Learning is a process of teaching and learning activities in which there is interaction between the teacher or lecturer and students. Good learning is a learning process that can help students develop themselves optimally and able to improve the spirit of learning to students, able to achieve the expected goals, and oriented to the needs and abilities of students. However, it cannot be achieved if one component in learning is lacking in support because essentially learning must be continuous between the learning components of one another. In learning, especially learning English there are four skills that must be mastered by students, namely listening, speaking, writing, and reading. To support those four aspects of learning language, especially English, students must also master the components of English, including grammar and vocabulary. One of the skills 
that must be mastered by students in English departmen is writing an essay.

Essay writing is one of the compulsory subjects that must be mastered by 3rd semester students of English language education at STKIP Muhammadiyah Kotabumi because by writing an essay they can express their ideas or thoughts in written form, while good writing is written that can provide information to the reader clearly. Writing is one of the language activities that are productive and expressive. Students generally assume that writing is very difficult. It was faced by many students in primary and secondary education, students in universities also face the difficulties of writing. The result of the complaint eventually became a public opinion, that writing was difficult (Sukirman in Khuzaenah and Herawati, 2017:150). To direct students to be able to write scientific papers, it must be done in stages. When talking about courses writing specifically writing essay in English is not easy, many components of writing an essay that must be mastered by students include grammar, Vocabulary, spelling, punctuation and capitalization.

According to Oshima and Hogue (1991:100), "an essay is a several paragraphs long writing instead of just one or two paragraphs and written about one topic, just as a paragraph is. However, a topic of essay is too complex to discuss in a paragraph.
Therefore, it must be divided into several paragraphs, one each major point. Then the tie must be all the paragraph paragraph together with adding an introduction and conclusion "in line with the opinion of Djuharie and Suherli in Khuzaemah and Herawati (2017:150) say that essay is a part (piece) of a writing, but can also be interpreted as a short essay, intact bouquet. Therefore, the essay is one type of writing that is often used as a test tool to measure one's intelligence. A knowledgeable person will be able to convey his ideas in a coherent, logical and interesting manner.

According to Oshima and Hogue (1991:101), there are three important parts in writing essay, such as:

\section{An introductory paragraph}

The introductory paragraph consists of two parts, the first is a few general statements about the topic of interest to the reader and the second is a thesis statement that is to deliver important or specific parts of the topic or plan that will be written. the thesis in writing an essay is the same as the topic or main sentence in writing a paragraph. There are four purposes in the introductory paragraph, they are (1) Submit the topic in the essay, (2) Provide a general description of the topic, (3) Declare all plans in the essay, and (4) attract the reader's interest about the topic. 


\section{Body}

The body consists of one or more paragraphs. Each paragraph develops a subdivision of the topic, so the number of paragraphs in the body will vary with the number of subtopics. The body is the longest part of the essay and can contain as many paragraphs as necessary to support the controlling ideas of the thesis statement. Each body paragraph has a topic sentence and several supporting sentences. It may or may not have a concluding sentence. Each body paragraph supports the thesis statement.

\section{Conclusion}

The concluding paragraph is the last paragraph of an essay. It has three purposes: It signals the end of the essay,It reminds the reader of your main points, and it leaves the reader with your final thoughts on the topic. The first part of the concluding paragraph summarizes the main points or repeats the thesis statement in different words. It may require one or more than one sentence. In the second part, you may add a final comment.

\subsection{PLAN and WRITE}

\subsubsection{PLAN}

Before writing an essay, the writer should applay the step of PLAN and WRITE as explained below:

\section{a. P: Pay attention to the prompt}

The first step of this is the teacher or lecturer focuses on helping the students to think a topic. According to Proett and Gill in Yunus et.al (2015:1.28), topic is a main core of an essay. This first step is the same as brainstorming. In line with the theory of Oshima and Hogue in Eliwarti (2012:11) states that the activity of brainstorming, the writer develop a topic or ideas and language related to a topic before beginning writing. To begin it, individually choose a topic, the topic chosen and narrow it to a specific focus. The next prewriting step is to generate ideas.

\section{b. L: List the Main Ideas}

In this step, the writer asked to get a topic and he/she produces the ideas from a topic. This step also called with listing. Listing is a brainstorming technique in which you think about your topic and quickly make a list of whatever words or phrases come into your mind. Your purpose is to produce as many ideas as possible in a short time, and your goal is to find a specific focus for your topic. According to Leki in Eliwarti (2012:12), listing is very useful to find example or specific information relates to the topic. In doing the listing the writer writes all the ides in the form of words or phrase that relates with the topic then categorize those ideas appropriate with the kind and omit the unappropriate ideas.

\section{c. A: Add Supporting Details}

In this step, the writer hoped can add the supporting details to support the main topic or main supporting point. 
$\mathbf{N}$ : Number your ideas

In this step, the writer has to put the supporting details sistematically based on the uses.

\subsubsection{WRITE}

After the series of PLAN step, the next step should be followed to write an essay is WRITE as explained as follows:

a. W: Work from your plan to develop your thesis statement

The thesis statement is normally the last sentence in an introductory paragraph (Oshima and Hogue, 2007:191). It has three purposes:(1). It states the specific topic of the essay,(2). It may list the subtopics of the main topic, and (3) it may also mention the method of organization.

It is also as the main important part in the intriductory paragraph of an essay writing.

\section{b. R: Remember your goal}

The writer should remember his/her goal of writing itself. In this step, the writer starts to write based on the plan that has been though from the beginning baesd on the topic chosen. According to Yunus et.al (2015:1.30), to get the goal of writing, the writer asked him/heself about the questions, "why do I write by choosing this topic", "what is the purpose I write it".

\section{c. I: Include transition words/signals}

Transition signals are important not only within paragraphs but also between paragraphs. If you write more paragraphs, you need to show the relationship between your first and second paragraph, between third paragraph, and so on. Think of transitions between paragraphs as the links of a chain. The links of a chain connect the chain; they hold it together. Similarly, a transition signals between two paragraphs links your ideas together (Oshima and Hogue, 1991:109).

\section{T: Try to use different kinds of sentences}

In writing an essay, the writer is able use some kinds of sentences, not only simple sentence, but also compound, complex, and compound-complex. According to Oshima and Hogue (1991:155), a sentence is a group of word that used to communicate the ideas. Every sentence is formed from one or more clauses and expresses a complete thought, and there are four kinds of sentences: simple, compound, complex, and compoundcomplex.

\section{e. E: Exciting}

To attract the readers, the writer has to make his/her writing exciting. In this step, the writer has to recheck the writing by revising and editing. In line with the theory of Oshima and Hogue (1991:114), the writer has to correct punctuation, spelling, and other errors in mechanics as well as changing some vocabulary words. Not only that he or she also corrects the grammar and improve the sentence structure. It it si completely satisfied with the writing, he or she is ready to make the final copy. 


\subsection{LEARNING MATERIAL}

Learning material or teaching material consists of knowledge, skills, and attitudes that students must learn in order to achieve competency standards. In detail, the types of learning material consists of knowledge (facts, concepts, principles, procedures), skills, and attitudes. The Ministry of National Education (2008:145-149) provides several definitions of teaching materials as follows; a. Teaching materials are information, tools and texts needed by the teacher/instructor for planning and reviewing the implementation of learning, b. Teaching materials are all forms of material used to assist teachers/instructors in carrying out teaching and learning activities in class, c. The materials can be in the form of written material or unwritten material, and $\mathrm{d}$. Teaching material is a set of material that is systematically written both in writing and not so as to create an environment/atmosphere that allows students to learn.

Moreover, Andi (2011:16) revealed that teaching materials are materials or subject matter that are arranged systematically, which is used by teachers and students in the learning process. Teaching materials are an important part of the learning process. Based on the previous theories, it can be concluded that teaching materials are the materials which can help the teacher/lecturer in teaching and learning process to get the achievement of the learning.

\subsubsection{TYPES OF TEACHING MATERIALS}

Teaching materials have many types which based on the form of them are printed, audio, audio visual, and interactive teaching materials. According to Prastowo (2011:40), teaching materials based on the form can be divided into four types, namely printed teaching materials, audio teaching materials, audio visual teaching materials, and interactive teaching materials. Another opinion is Amri \& Ahmadi (2010:161), teaching materials consist of four types, including visual teaching material, audio teaching material, audio visual teaching material, and interactive multi-media material. The following is an explanation of the teaching materials according to Prastowo when viewed from the form:

1. Printed teaching materials, which are teaching materials prepared in paper used for learning or submitting information on the teaching materials, such as handouts, books, models, student worksheets, brochures, leaflets, wall charts, photos or drawings, and models .

2. Hearing teaching materials (audio) are teaching materials that use the system using direct radio signals that can be played and heard, such as cassettes, radio, vinyl records, and compact disk audio. 
3. audio visual teaching materials, which are teaching materials that use audio signals and combined with moving images, such as movies and video compact disks.

4. Interactive teaching materials, namely a combination of two or more media (audio, text, graphics, images, animation, and video) that are manipulated or treated to control a natural command and / or behavior of a presentation, namely compact disk interactive.

\section{METHODS}

The research method used in this study is the research and development method. follows.
Research and development is carried out to develop teaching materials for essay writing through PLAN and WRITE for third semester students majoring in English education STKIP Muhammadiyah Kotabumi which will then be used in the learning process. The research method that will be used is the research and development method. Research and development is carried out to develop essay writing teaching materials which will then be used in the learning process. Sugiyono (2012: 298) stated that teaching materials were developed by following the steps shown in the figure as

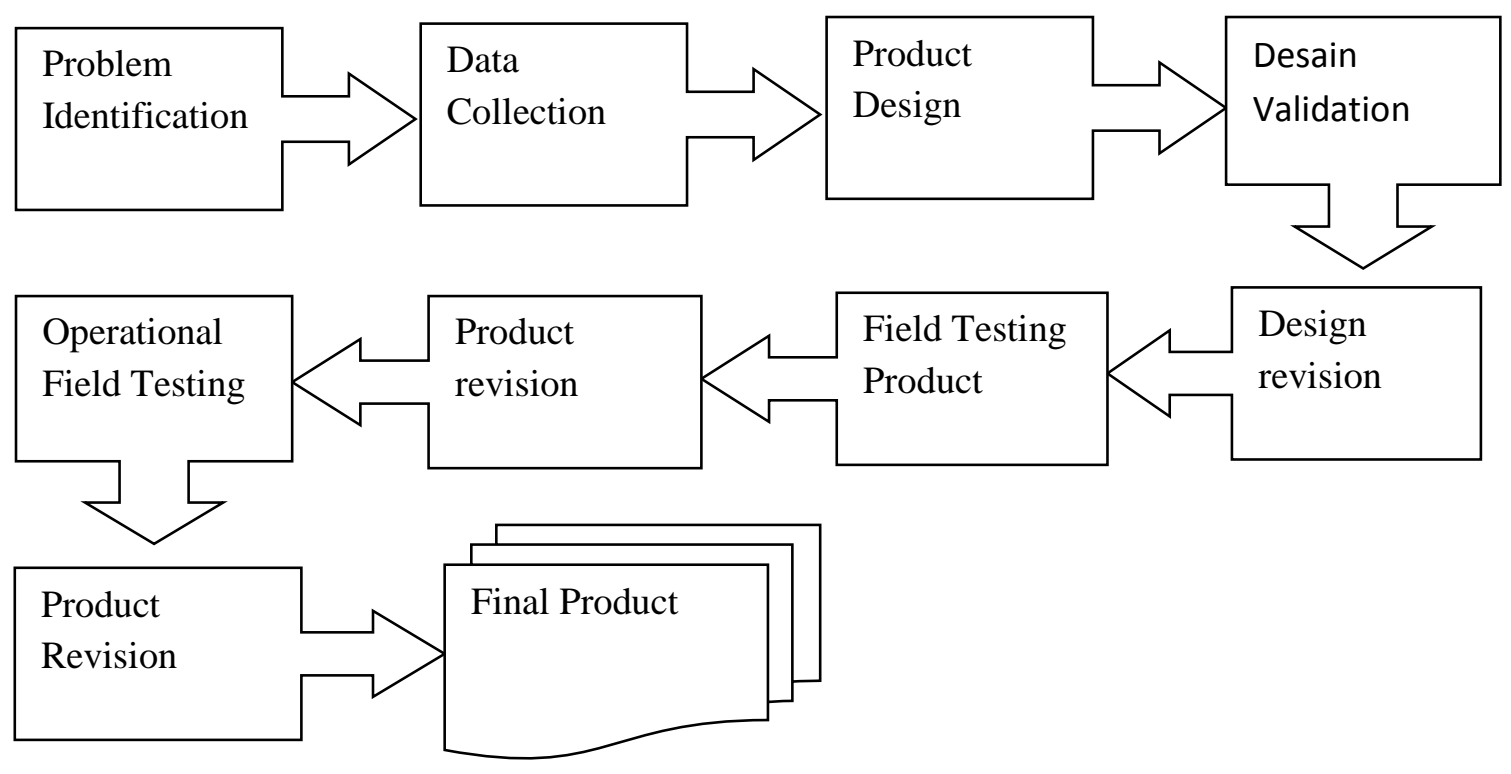

Figure 1

Steps for Research and Development Methods

(Sugiyono, 2012: 298)

Based on the figure 1 above, it consists of 10 design, (4) ) design validation, (5) design steps, but here the researcher only limited it revision, (6) field testing product, and (7) to the 7th step, they are: (1) problem product revision. It was done because identification, (2) data collection, (3) product considering the time in developing the 
teaching material was immediately used. In this research, design validation or product validation was carried out by a team of material experts and a team of media or design expert. In the field testing product only carried out in one class, that is the third semester students of English education program of STKIP Muhammadiyah Kotabumi. The explanation of the steps of research and development in this research is explained as follows.

\subsection{RESEARCH AND DEVELOPMENT PROCEDURES}

This teaching material was developed using several development procedures which included (1) problem identification, (2) data collection, (3) product design, (4) design validation, (5) design revision, (6) field testing product, and (7) product revision. These development stages can be explained in more detail as follows:

\subsubsection{Problem Identification and Data Collection}

This research and development is to observe the learning process of Essay Writing courses for students of the third semester students of English education program of STKIP Muhammadiyah Kotabumi.

a. Observation

According to Nasution in Sugiyono (2012:226), "observation is the basis of all knowledge" as the opinion of Marshall in
Sugiyono (2012:226) states that through observation, researcher learn about the attitude/behavior and meanings of them. Based on observation made by researcher who is also lecturer of Essay Writing subject herself, based on observations with some third semester students English education program of STKIP Muhammadiyah Kotabumi are still less active and less enthusiastic in participating in Essay Writing subject in the classroom seen when they do the tasks or exercise are still not understand and confused, so the results of the tasks and exercises they do are not good enough and get less satisfactory grade, so researcher assumes new ideas or ways to be developed so that they are more motivated in following the learning process, especially in Essay Writing courses by developing Essay Writing teaching materials to help and make it easier for them to have learning references. b. Interview

According to Esterberg in Sugiyono (2012:230), the interview is a meeting of two people/informants to get information and ideas through question and answer, so that the meaning can be constructed in a particular topic. This is done by researcher to find or get problems that must be conducted. In this research, interview was conducted by several third semester students English education program of STKIP Muhammadiyah Kotabumi to find out what 
the problem they faced in attending Essay Writing subject.

\subsubsection{Product Design/Preparation of Teaching Materials}

At this stage, the researcher began to compile hand book which is one of the main activities in this research that is to produce a product. To compile the hanbook is based on the learning outcomes based on curriculum of KKNI and Semester Learning Plan or RPS in the Essay Writing.

\subsubsection{Design Validation}

Design validation is an activity process to assess whether the product design is more effective in product oxidation can be done by presenting several experts that are relevant to the product designed to find out the weaknesses and strengths of the product (Sugiyono, 2012:302). After the instructional materials are prepared, the teaching materials need to be validated before being used as one of the handbooks in Essay Writing subject, the teaching materials are validated by 2 experts (validators) relate with the science. To assess the instructional materials, the researcher used a teaching material assessment sheet using a questionnaire consisting of 22 items with 4 answer choices, namely very poor, poor, good, very good. after. then there are input, comments or deficiencies in the preparation of the teaching material. In addition also validation is carried out by 1 design expert and media through a questionnaire consisting of 35 statements to give responses relates with teaching material by selecting one of the answer choices according to each answer which is very poor, poor, good, very good.

\subsubsection{Design Revision}

After the teaching material has been validated by the experts and design and media expert through discussion and by using questionnaire to know the weaknesses of the instructional material, the next step is the researcher needs to analyze the questionnaire and revise based on responses or comment related to the instructional material that has been compiled, so that teaching material will be well organize.

\subsubsection{Field Testing Product}

Field testing product is conducted on the third semester students of the English education program by giving written test (writing essay) to determine the effectiveness of the teaching material that has been prepared by the researcher. Beside giving test to students, researcher also gave questionnaire to students consists of 25 statements 15 positive statements and 10 negative statements, and there are 4 choices of answers including strongly agree, agree , disagree, and strongly disagree. 


\subsubsection{Product Revision}

The last stage is the seventh stage carried out by the researcher in this research namely product revision. At this stage, the researcher revised the revisions based on the findings that occur during the implementation of the learning.

\subsection{Place and Time of Research}

The research was carried out at STKIP Muhammadiyah Kotabumi in the 3B semester students of the English education program in academic year 2017/2018.

\subsection{Data Analysis}

\section{Data Analysis of Product}

To analyze the learning material validation, the researcher used descriptive quantitative and descriptive qualitative, the quantitave data in the form of suggestion or comment relates with the learning material, and to analyze the quantitative data in the form of numbering/skor of likert scale with 4 scale, such as 4 for very good, 3 for good, 2 for poor, and 1 for very poor.

\section{Data Analysis of Field Testing Product}

a. Analysis of Test

To analyze the students test, the researcher used mean, modus, and median. To calculate the mean used mean of single data by calculating all data then divided by the total data (Siregar, 2010:20). The formulation can be seen as follows.

$\bar{x}=\frac{\sum X i}{n}$

\section{Description:}

$\sum X i=$ score of each data

$\bar{x}=$ mean

$\mathrm{n}=$ total of data

To calculate modus done by finding the score which often appear among the all data. The formula as follows:

$\mathrm{Me}=1 / 2(1+\mathrm{n})$

Description:

$\mathrm{n}=$ total of data

b. Analysis of Questionnaire

to analyze the result of the questionnaire can be used the formulation below:

Table 1

Interval Score in Each Criteria

\begin{tabular}{|l|c|c|}
\hline No & Criteria & Interval Score \\
\hline 1 & Very good & $(\mathrm{S} \min +3 \mathrm{p}) \leq \mathrm{S} \leq \mathrm{Smax}$ \\
\hline 2 & Good & $(\mathrm{S} \min +2 \mathrm{p}) \leq \mathrm{S} \leq(\mathrm{S} \min +3 \mathrm{p}-1)$ \\
\hline 3 & Poor & $(\mathrm{S} \min +\mathrm{p}) \leq \mathrm{S} \leq(\mathrm{S} \min +2 \mathrm{p}-1)$ \\
\hline 4 & Very Poor & $\mathrm{S} \min \leq \mathrm{S} \leq(\mathrm{S} \min +\mathrm{p}-1)$ \\
\hline
\end{tabular}

Source From Khayati (2015:63)

Description: 
S : Score of respondent

Smin : Minimum Score

Smax : Maximum Score

$\mathrm{p} \quad$ : Lenght of class interval

III. RESULT AND DISCUSSION

\subsection{Result of Problem Identification and Data Collection}

To collect data in preliminary research, researchers conducted interview and observation on third semester students of the English language education program of STKIP Muhammadiyah Kotabumi academic year 2017/2018. Based on the observation and intervieware as follows:

a. During learning of Essay Writing course, most of students were still not active and less participating during the learning process.

b. Most of them are still confused when they do the exercises, even though they have been explained before.

c. Students find difficult to start writing an essay.

d. Their essay writing are still not well organized.

e. The guidance book that they used were not enough to them to support their learning especially essay writing subject.

\subsection{Result of Product Design}

The learning material designed in the form of a handbook for Essay Writing sucject that consist of title, preface, table of contents, list of tables, list of picture, it consists of 7 Units of teaching material. The preparation of this teaching material is based on the learning objective that must be achieved by students in the learning outcomes courses in the syllabus and Semester Learning Plan (RPS).

\subsection{Result of Design Validation}

Based on the result validation from 2 experts of the material based on three aspects, namely the feasibility aspect of the content, the score ois 62 or $86 \%$ of the total score 72, while the aspect of material presentation with a score of 70 or $87.5 \%$ of the score the highest is 80 , and the aspect of grading with the total score is 22 or $91.6 \%$ of the highest score is 24 . It can be concluded that the three aspects of the design of the teaching material are very good. In detail can be seen in the table below: 


\begin{tabular}{|c|l|c|c|c|}
\hline No & \multicolumn{1}{|c|}{ Aspects } & $\begin{array}{c}\text { Total } \\
\text { Score }\end{array}$ & $\begin{array}{c}\text { Total of } \\
\text { highest } \\
\text { score }\end{array}$ & Category \\
\hline 1. & Content appropriateness & 62 & 72 & Very good \\
\hline 2. & Material presentation & 70 & 80 & Very good \\
\hline 3. & Grading & 22 & 24 & Veru good \\
\hline
\end{tabular}

The score of design and media expert can be seen in the table below:

\begin{tabular}{|l|l|c|c|l|}
\hline No & \multicolumn{1}{|c|}{ Aspects } & $\begin{array}{c}\text { Total } \\
\text { Score }\end{array}$ & $\begin{array}{c}\text { Total of } \\
\text { highest } \\
\text { score }\end{array}$ & Category \\
\hline 1 & Feasibility integrity & 83 & 92 & Very Good \\
\hline 2 & Language feasibility & 45 & 48 & Very Good \\
\hline
\end{tabular}

Based on the table above, it can be concluded that the result of the assessment from the design of learning material by design and material expert based on the graphical feasibility aspect with a total score of 83 or $90 \%$ of the highest number of scores 92, so that it is classified as a very good category, and aspects of language feasibility obtained a value of 45 or $93.7 \%$ of the highes score 48 so that it is included in the very good category.

\subsection{Result of Field Testing Product}

Field testing product was conducted on 28 May 2018 through test and questionnaire given to 20 students of third semester of B Class of English education program of STKIP Muhammadiyah Kotabumi. based on the result of writing test of essay shows that from 20 students, 13 students who got the score more than 80 or $65 \%$, and 7 or $35 \%$ students who got score under 80. And the the mode score is 70 , the score of median is 75.

Based on the questionnaire result shows that based on the three aspects: presentation/display, material presentation, and benefit. It can be seen below:

\begin{tabular}{|c|l|c|c|c|}
\hline No & \multicolumn{1}{|c|}{ Aspects } & $\begin{array}{c}\text { Total of highest } \\
\text { score }\end{array}$ & Total score & Category \\
\hline 1. & Display & 480 & 411 & Very good \\
\hline 2. & Material presentation & 720 & 611 & Very good \\
\hline 3. & Benefit & 800 & 689 & Very good \\
\hline
\end{tabular}

\section{CONCLUSIONS AND SUGGESTIONS}

Based on the result of research and development of Essay Writing teaching materials through PLAN and WRITE in STKIP Muhammadiyah Kotabumi, it can be concluded that research and development by 
following the 7 steps of 10 steps of R \& D method include: preliminary studies, data collection, design/preparation of teaching material, validation of teaching materials, revision of teaching materials, testing of teaching materials, and the last revision of teaching materials. The instructional material is compiled of 7 Units. Teaching material is prepared referring to the academic guidebook and Semester Learning Plan (RPS) in one semester, namely for the third semester students of the English Education Program. Teaching material has also been validated by two material experts and one design and media expert, based on the results of the teaching material validation by these three that the teaching materials are in the very good category and are worthy to be tested in the next stage. Test was conducted to determine the effectiveness of teaching material. Field testing product through essay writing test and questionnaire. Based on the test results, it can be concluded that teaching material that has been developed is very effective for learning Essay Writing subject, it can be seen by the average score of $3 \mathrm{~B}$ students got 80.3 higher than the score of $3 \mathrm{~A}$ is 74.4, while based on the results of questionnaire, the three aspects of teaching material is in very good category.

\subsection{Suggestions}

Based on the results of the research and the conclusions above, there are some suggestions as follows:

\section{Lecturers:}

The lecturers who apply Essay Writing subject can apply their learning, especially when teaching by using the steps of teaching materials through PLAN (Pay attention to the prompt, List the main ideas, Add supporting details, Number your ideas) and WRITE ( Work from your plan to develop your thesis statement, Remember your goal, Include transition words / signals, Try to use different kinds of sentences, Exciting) through these steps will make students write essays more systematically and easily.

\section{Next researcher}

The results of the research in the form of printed teaching material (handbook) for Essay Writing subject is expected to provide benefits and as inspiration for next researchers to continue and develop more varied writing essay teaching material.

\section{REFERENCES}

Amri, S. Dan Ahmadi, I.K. 2010. Kontruksi Pengembangan Pembelajaran. Jakarta: Prestasi Pustaka.

Andi. 2011. Bahan Ajar dan Pengembanganya. Jakarta: Rineka Cipta. 
Departemen Pendidikan Nasional. 2008. Pengembangan Bahan Ajar. Jakarta: Ditjen Diknas.

Eliwarti. 2012. Penerapan Teknik "Brainstorming" untuk Meningkatkan Kemampuan Menulis Esai. Riau: Universitas Riau.

Khayati, Fitrotul. 2015. Mengembangkan Modul Matematika untuk Pembelajaran Berbasis Masalah. Tesis Magister pada FKIP UNS. Bandung. Tidak diterbitkan.

Khuzaemah, Emah dam Herawati, Lilik. 2017. Pembelajaran Menulis Esai Menggunakan Model CIRC Berbasis Life Skills. Cirebon: IAIN Syekh Nurjati.

Oshima, Alice. And Hogue, Ann. 2007. Writing Academic English. Third Edition. New York: Pearson Longman.
Oshima, Alice. And Hogue, Ann. 1991. Writing Academic English. Second Edition. Cambridge: Addison-Wesley Publishing Company.

Prastowo, A. 2011. Panduan Kreatif Membuat Bahan Ajar Inovatif. Yogyakarta: Diva Press.

Siregar, Syofian. 2012. Statistika Deskriptif untuk Penelitian. Jakarta: Rajawali Pers.

Sugiyono. 2012. Metode Penelitian Pendidikan Pendekatan Kuantitatif, Kualitatif, dan R\&D. Bandung: Alfabeta. 